\title{
Exploring the Iconicity of Godzilla Popular Culture. A Comparative Intercultural Pespective: Japan-America
}

Изследване на иконичността на годзила в популярната култура. Сравнителен междукултурна перспектива: Япония-Америка

\author{
Crînguța Irina Pelea \\ Крингута Ирина Пелеа
}

Department of Communication and PR, Titu Maiorescu University, Buchares, Romania Департамент по комуникации и PR, Университет Титу Майореску, Букурещ, Румъния

\begin{abstract}
Author Note
Crînguța Irina Pelea https://orcid.org/0000-0002-1080-9650

Crînguța Irina Pelea is Lecturer in Titu Maiorescu University, Romania.

The author has no known conflict of interest to disclose.

Correspondence, concerning this article should be addressed to Crînguța Irina Pelea 22 Strada Dâmbovnicului Tineretului, București 040441, Romania. Email: cringuta.ir-
\end{abstract} ina.pelea@gmail.com

\section{Бележки за автора}

Крингута Ирина Пелеа https://orcid.org/0000-0002-1080-9650

Крингута Ирина Пелеа е преподавател в Университет Титу Майореску, Румъния. Няма конфликт на интереси

Email за кореспонденция във връзка със статията: cringuta.irina.pelea@gmail.com 


\begin{abstract}
The present study aims to compare the representation of Godzilla or Gojira, considered one of the most representative cultural icons of Japanese cinematography. The author adopts a comparative intercultural perspective, one that integrates research into a much broader sociohistorical context, with particular attention to how the culturally enhanced linguistic component influences the symbolism incorporated by Godzilla in Japan and how it is reimagined in its Hollywood counterpart.Hence, the theoretical section brings into discussion relevant and previously unpublished Japanese-language literature on Godzilla, thus trying to balance both Western and Japanese perspectives academically. The present research applies the methodology of narrative analysis to investigate from a comparative perspective significant differences existing in the narrative portrayal of the iconic monster in "Shin Godzilla" (Japan, 2016) versus "Godzilla: King of the Monsters" (the USA, 2019). Gojira is inherently Japanese.

Keywords: Shin Gojira/ Godzilla, a cultural icon, popular culture, Japan, USA
\end{abstract}

\title{
Резюме
}

Статията има за цел да сравни представянето на Годзила или Годжира, считана за една от найпредставителните културни икони на японската кинематография. Авторьт се опитва да балансира както западната, така и японската гледна точка. Прилага се методологията на наративния анализ, за да изследват от сравнителна гледна точка различията, съществуващи в разказа на изобразяването на емблематичното чудовище в „Shin Godzilla” (Япония, 2016) спрямо „Godzilla: King of Monsters" (САЩ , 2019). Невъзможно се оказва да се пренесе или преведе културната специфика на емблематичния звяр в медийния контекст на Северна Америка, въпреки възпроизводството на почти същия филмов разказ: Годжира по своята същност е японска.

Ключови думи: Shin Gojira/ Godzilla, културна икона, популярна култура, Япония, САЩ.

ARTICLE INFO:
Original Article
Received: $15,03.2020$
Revised: $20,03.2020$
Accepted: $25,03.2020$

Проблеми на постмодерността / Postmodernism Problems Vol. 10, No. 1, 2020, ISSN: 1314-3700, https://pmpjournal.org https://doi.org/10.46324/PMP2001018 


\section{Exploring the Iconicity of Godzilla Popular Culture. A Comparative Intercultural EX \\ Pespective: Japan-America}

\section{Literature review}

The film “Godzilla," produced and released by Toho Studios in 1954, was a blockbuster success since its premiere, and it was followed by 32 Japanese sequels and other three North American versions. Godzilla (as “Gojira” in original Japanese word，ゴジラ」) recounts the tale of an ancient monster, kaiju, deformed by the atomic radiation, which usually embarks on destroying Japanese cities, after being forced to abandon its natural habitat. The beast whose name represents a combination name is a portmanteau of the Japanese words "whale" (鯨 kujira) and "gorilla” (ゴリラ gorira), became instantly "a model for the development of the purely Japanese film genre called kaijū eiga” (怪獣映画, literally “monster films”) (Glownia, 2013, p. 68).

\section{Godzilla: an allegoric representation of Japanese socio-political traumas}

Its revenge on humankind becomes a strikingly visual and highly disturbing allegory for the devastating effects of atomic weapons, and radioactive death, given that the context of production manifested a secure emotional and also temporal connection to the tragedy of the nuclear bomb and Japan's quest of a new national identity. More specifically, one cannot overlook the timing, otherwise said, the fact that the atomic bombing of Hiroshima and Nagasaki, the first and only ever cities to experiment with the effects of nuclear weapons, happened less than a decade before the release of Godzilla.

Moreover, he becomes a coherent cinematic expression for the trauma of the atomic war, or otherwise said, the ultimate signifier of the nuclear holocaust, mass-destruction, and the dramatic economic and social development of a country in agony, thus it invites to a broader reflection on the nuclear theme. Similarly, the visual aggressiveness of the scenes where Godzilla attacks cities replicates almost identically the horrors witnessed by Japan when Hiroshima and Nagasaki were bombed.

Director and screenwriter Ishiro Honda describes as following the connection between Gojira and his experience during World War II: "Most of the visual images I got were from my war experience. After the war, all of Japan, as well as Tokyo, was left in ashes. The atomic 
bomb had emerged and destroyed Hiroshima. If Godzilla had been a dinosaur or some other animal, he would have been killed by just one cannonball. But if he were equal to an atomic bomb, we wouldn't know what to do. So, I took the characteristics of an atomic bomb and applied them to Godzilla" (Ryfle, 2005, p. 47).

Godzilla stands out as a metaphor for peace instead of war, for accepting the human condition as being humble, and for respecting the boundless, absolute, and unconditioned power of nature. The narrative line hides behind the label of "science fiction" a painful and problematic reality: when the balance between human and nature is destroyed, this marks the end of the harmonious world, and as Honda added "in the universe, there is no difference between my life, humans' life and any other life. We live within this connection" (Honda, 2010, p. 231).

Japanese film and literary critic Saburo Kawamoto links the birth of Godzilla with the spirits of the dead soldiers in his study "Why is Godzilla so dark?" (Kawamoto, 1983, p. 25) assuming that Godzilla could metaphorically stand as a conglomerate for the souls of the ones who died in the ocean and came back holding a deep-seated grudge against Japan's nation. Kawamoto's theory of „Godzilla as the spirits of the dead” shows that the cinematographic franchise surpasses its condition of portraying the post-war trauma, chaos, and recovering economy; it also becomes "a requiem" for the soldiers who died in the ocean and the victims of the World War II (“heishi no bōrei”, 兵士の亡霊), a symbol standing for peace and abolishing nuclear weapons (Kawamoto, 1983,8). Therefore, the dark tone of the story lies in the muchneeded atonement and repenting of the post-war generation who lives but must not forget the sacrifices of the ones who perished during the war. This symbolic and allusive connection explains why the reception process of Godzilla is so strikingly different in Japan versus the USA.

Just like Japanese people, this monster is an innocent victim of the atomic bomb, whose habitat has been irreversibly destroyed by the nuclear force: "Godzilla has a dual nature: one of being the perpetrator who ravages he human world, and in the same time one of the victims whose peace has been threatened by science... If Godzilla was a single violent monster, maybe we could have applauded innocently at the destruction of the National Diet Building and Ginza. Perhaps we could have said, "Cheers" at the death of Godzilla" (Kawamoto, 1983, pp. 25-28). 
Although the usual and dominant reading of Godzilla pays tribute to the prevalent leitmotif of nuclear irradiation and the threat of potential future nuclear wars, the film engages other uncanonical and unexpected interpretations.

\section{The aesthetics of destruction}

Strangely, the Japanese audience manifests an unexpectedly high degree of sympathy towards Godzilla, and it is not uncommon for many Japanese moviegoers to leave the theatre in tears, after witnessing the death of the monster (Koukoku Project, 2013). "Unless you are a fan without much compassion, probably you will not be able to see the death of this monster king without any tears or feeling sadness..." stated historian William M. Tsutsui (2005, p.96).

The unexpected wave of sympathy and sadness felt by the Japanese public when witnessing the death of Godzilla exposes the common enemy of the monster and humans as well: the atomic bomb. Similarly, assistant director Kouji Kajita stated in an interview, „At the preview of the movie, I heard the voice of a woman saying „Poor Godzilla. “ Then I had the feeling that he was not an odious monster but that he had become a character to empathize with" (World Photo Press, 2009, p. 31).

Given the above mentioned, at least three philosophical and aesthetic perspectives of destruction are portrayed in the film: the sympathy towards the dying enemy, the self-sacrifice or the self-renunciation, and the suicide (Koukoku Project, 2013). Furthermore, if one empathize with the enemy, can this monster still be considered an enemy? The "friend-enemy dichotomy" remains ambiguous, which culturally corresponds to the tendency of Japanese culture and language to maintain a certain degree of ambiguity and not divide everything into "black and white".

Moreover, there are other theories intimately connecting the existence and evolution of Gojira to the historical, cultural, and social context of Japan, therefore making even more interesting the transition and appropriation of this cultural icon within American popular culture. For instance, folklore scholar Norio Akasaka points out the fact that Godzilla never attempts to destroy the Imperial Palace (Asaka, 1992) or temples, yet shows no mercy to other buildings or the National Diet Building. 
Much has been speculated around this discriminate destruction. Was it to prevent potential protests from occurring after the release of the movie, or was it because Godzilla shares a symbolic relation of immutable ancestry with nature and with the past of Japan? Godzilla's existence comes as a destruction vector and a perennial warning for those who have forgotten to have faith in their country and opted for an unrestrained scientific evolution, out of human arrogance.

Hence, as an avatar of threat and terror towards the atomic bomb, it becomes from the very beginning an enraged protector and guardian of Japanese traditional culture. By destroying solely the cities, he wipes out any trace of the Western civilization which exists in nowadays Japan (Tabata, 2005, p. 16), whose post-Meiji nation has made collective and sustained efforts to accept and integrate western culture. The bestial figure highlights the problematic process of modernity and forced globalization, as well as the economic, social, and political system of post-war Japan. As the product of Japan's post-war anxiety, following the devastating bombing of Hiroshima and Nagasaki, his distorted, hyperbolic and grotesque image stands for the physical and mental suffering endured by the victims of the atomic bombs; more specifically, "even Godzilla's skin, thick and furrowed like the keloid scars that afflicted the survivors of Hiroshima and Nagasaki, evoked the agony of irradiation" (Tsutsui, 2017, p. 33).

However, what this ancient and irradiated monster penalizes is not the Japanese people, but the aggressive and proactive westernization which takes place within a massive process of cultural fusion. For instance, the skyscrapers of Tokyo, so frequently destroyed in Godzilla movies, represent nothing more than the symbol of the much blamed western culture and civilization which permeated Japan, as the primary influence force. Godzilla, through its birth and behavior, has conveyed into a symbol of fighting against the evil of globalization, cultural homogeneity, and aggressive assimilation. At the same time, its persistent rage is likely to be associated with the fear of experiencing a permanent and irreversible loss of the Japanese traditions in a world dominated by modern technology, materialism, consumerism, otherwise said, pregnant superficiality.

By symbolizing the struggle between scientific advancement and the fragile environmental preservation, he marks the renaissance of post-war Japan, a society that, with its 
fading grip on historical tradition and an ambivalent attitude toward the future, seems to emblemize Victor Turner's definition of the liminal as being "Betwixt-and-Between" (Turner, 1967). Godzilla, through its destructive power, questions the seemingly enchanting modernity promised by the near future. If one forgets his past, ancestors, tradition, and culture should be penalized accordingly; thus the monster's implicit purpose is to instill a sense of nationalism and community to the Japanese audience, by keeping alive the tragic memory of the past war. Therefore, for the Japanese viewer, the monstrous figure becomes a signifier of symbolic rebirth and yet salvation from losing one's identity, as opposed to terror and fear of the unknown.

What fulfills Godzilla's identity as Japanese is what has been described by Norihito Kato as his “homing instinct” (“kisō honnō”, 帰巣本能) (Kato, 2010). The reason why the monster attacks Japan, at least in every Japanese movie, added Kato, is because this is his natural habitat and he always returns home. Nevertheless, despite having its premiere in 1954 and the relative simplicity of the plot, Godzilla movies have never ceased to be connected to the realms of contemporary Japanese society. Albeit the nuclear metaphor constitutes an essential ingredient in its' identity shaping process, the iconic bestial figure also plays the critical role of a barometer indicating significant events, disasters, fluctuations of public moods, the evolution of social anxieties, or hot social and political topics regarding Japan. As Tsutsui (2005) adds: „Even in later decades, as the series targeted a much younger and less politically aware demographic, the Godzilla films continued to address some of the weighty issues confronting Japanese society: corporate corruption, pollution, school bullying, remilitarization, and rising Japanese nationalism, just to name a few" (p. 208).

\section{Godzilla: the fury of a god in a postmodern urban legend}

Going beyond the socio-political interpretation of the series, Godzilla's existence is intimately connected with the basics of ancient Japanese mythology, and it has been speculated that as he represents the reincarnation of the Asian dragon, he acts as an angered god, but by no means can he be considered a genuine enemy of the humans. Thus, he becomes "the sacred monster" of a postmodern Japanese legend, which has been continuously misidentified and misunderstood, incorporating one or another wide-lensed fantasy for both the humans' fears aspirations: "Godzilla is a sacred beast sent by God to warn us about the horror of the nuclear 
war". (Tanaka, 1984, p.10) Or otherwise said, this angry god of nature "has been released in the middle of this proud humankind, as a divine messenger" (Toho, 1984, p.1), and despite many efforts to defeat him, "he is invincible; he is almighty powerful, therefore he doesn't communicate at all with the people. One can say with confidence that Godzilla is a god" (Tanaka, 1991, p. 221). Moreover, by connecting to a greater dialogue of omens, he personifies a malevolent divine creator whose longevity within the globalized area of popular culture can be explained in a broader geographical and cultural context: "Jurassic Park is a movie with dinosaurs, whereas King Kong is a monster movie. In both South and North Korea, monster movies have been directed, yet they have been only one shot productions. They haven't created long series or long-lasting monsters such as Godzilla, Mothra, Gamera or many others the way Japan did. Why did the Japanese continue to produce so many monster films until nowadays? This situation happens because the monster, for Japanese people, is a malevolent god, and the monster films represent, in fact, Japanese legends" (Takei, 2016). A case in point is the legend "Yamata no Orochi Taiji (八岐大蛇退治 or the “Slaying of the Great Eight-Headed Serpent”, frequently mentioned as having significant importance in establishing the narrative line of the film (Hashimoto, 2016, p.186). There are several similarities the movie franchise share with this iconographic legend related in the court chronicles Kojiki 古事記 (Record of Ancient Matters, 712) and Nihon shoki 日本書紀 (Chronicles of Japan, p. 720). Both Godzilla and Yamato have a deep connection to water, and their tales represent a verbalization and visualization of the universal dragon-slayer myth, each one adapted in consequence to the ever-changing social, cultural, or economic circumstances of Japan. Thus, through its deep mythical roots anchored in the ancient mythological world and legacy of Japan, the monster movie franchise reveals narrative structures and archetypal themes that interweave mythology into the shocking reality of a nation who faced a mass-destruction. As a syncretic god of destruction ("shinbutsu shūgō", 神仏習合), Godzilla represents equally a reflection of the syncretic nature of religion in Japan, by displaying concomitantly Shinto and Buddhist values.

In Shinto, where nature is considered inherently perfect, divine and pure, "kami," (神) the heavenly beings, the nature spirits are worshipped incessantly, thus as a dragon of water, Godzilla embodies the water aspect of the natural world. Albeit hidden, yet omnipresent, the 
gods existing in the Shinto system of belief can be kind and beyond generous or malevolent and viciously destructive. Therefore, in the context of this above mentioned religious syncretism, Godzilla can be perceived as an angered god of nature, displaying its destructive nuclear power ("kami no saraburu chikara"，神の荒ぶる力) and not as a monster per se, as one is described in European mythology.

Finally, it is undeniable that during the past 60 years, Godzilla has experimented with radical transformation in shape, motivations, and character by playing various roles that are culturally adapted to the production context. However, despite the flexibility of the franchise, this popular icon continues to be firmly ingrained in Japanese popular culture intimately associated with Japanese unique cultural, social, and historical experiences and events.

\section{Method and results. Research objectives, employed}

The decision to focus on exploring the national and cultural specificity of the famous icon was prompted, first of all, by the atypical and exceptional surge of interest manifested nowadays towards Japanese popular culture, and second of all, by the dissemination, popularization and more extensive consumption of cultural products such as Godzilla on an international scale. The primary research objective is to investigate the cultural characteristics of Gojira or, otherwise said, Godzilla, starting from the presumption that there are two different cultural icons engaged into a similar narrative universe but bearing a strikingly different symbolism, vanished in the global flow of the film industry.

Therefore, it is assumed that, with the mobility and mutability of this iconic cultural monster contextualized outside Japan, its rhetorical and allegoric power are significantly diminished, and the American installments are prone to be considered ephemeral mass productions which lack the consistency of the originals. In the research section, "Gojira" and "Godzilla" will be attached to the Japanese, respectively, American productions, as a convention to underline the existing cultural and identity differences. To achieve this objective, the author will employ the narrative analysis of the scripts, by focusing on the latest Japanese and American cinematographic productions as of December of 2019: “Shin Godzilla” (新ゴ ジラ, 2016, Japan, Production Company: Toho, co-directed by Hideaki Anno and Shinji Higuchi) and "Godzilla: 
King of the Monsters" (2019, USA, Production Company: Legendary Pictures, directed by Michael Dougherty).

The author has deliberately chosen to exclude "Godzilla: Planet of the Monsters" (2017) and its two sequels, "Godzilla: City on the Edge of Battle" and "Godzilla: The Planet Eater". While released in 2018, these three productions are animated films that are prone to follow the patterns and the visual and discursive conventions of "anime".

The scripts are available online, and by occasionally referring to the original text instead of the translated version (in the case of the Japanese language script), the present study aims towards analyzing comparatively the untranslatable cultural essence encompassed in the cultural icon's portrait, in both Japanese and American media context. If necessary, to support the asserted point of view, references to additional Japanese productions or visual cues will also be included. Another hypothesis associated to the objects referenced in the previous paragraphs is that integrating the iconic beast into the global matrix of media texts, or at least striving to enhance its global mobility is affecting its cultural authenticity, national identity, as well as the rhetoric of nationalist sentiment, given that the Japanese public feels little to no connection to the Americanized Godzilla.

The reason why this particular research method was chosen is related to its potential to interrogate Gojira' and Godzilla's nationality and cultural specificity, given the necessity of reconsidering not only the sociocultural but also the linguistic context of production. Moreover, regardless of the incontestable similarities of the generic, visual, and narrative structure, many intertextual references are lost in the translation, making the series facing a major identity crisis, on material, aesthetic, and discursive levels. Hence, there is a high hope to place equal emphasis on the cultural imprint of Japanese language over the plot, which tends to be ignored or at least lost in the translation, in the dense web of academic studies dedicated to the iconic beast.

\section{"Shin Gojira" (2016) versus "Godzilla: King of the Monsters" (2019)}

Both cinematographic productions have garnered much global media attention, yet only the Japanese film has drawn record audiences, while its American counterpart has turned to be a financial failure in terms of box office success. Therefore, it is at least striking how these two films, albeit produced at a time difference of only three years and adopting a similar narrative 
line, have turned to be almost exact opposites in terms of critical reception, not only productionrelated aspects, such as cast, crew, situational context or language.

While „Shin Gojira” became the highest-grossing live-action Japanese film of the year 2016, not much strategic effort has been invested in releasing or promoting it on international markets. On the contrary, „Godzilla: King of the Monsters“ has received mixed reviews and, even though it has benefited from its extended-release outside the North American space, its total earnings are far from covering the production budget, despite the initial expectations. The following analysis will develop four interpretative modes, which have been identified as reflecting the noticed differences: the symbolism encompassed in the story, cultural encoding and reception differences, portrayal of the iconic beast, and other characters, respectively, the imaginary and aesthetics of destruction.

\section{The symbolism encompassed in the story}

The first significant difference, which is to be noted when comparing the scripts, lies in the narrative symbolism. Shin Gojira bears a high resemblance to the installment of 1954, and likewise, comes to destroy Tokyo, thus reimagining apocalyptic dark Japan set in the post-nuclear-bombing era. The irradiated monster can easily stand for some recent disasters which happened in Japan and for the seemingly incompetent behavior of the government regarding the 2011 Fukushima Daiichi nuclear disaster. However, the film surpasses the perpetual metaphor of nuclear destruction confiscated by every installment of the franchise and stands out as a dark political satire which epitomizes, on the one hand, the bureaucracy and inefficiency of the Japanese government, and on the other hand, the bitterness of the symbiotic political relations between Japan and USA.

Following the historical preference of Japanese cinema for ambiguous end scenes, partially resolved central issues, and teasing future installments, a similar ambiguity pervades the plot of Shin Gojira. For instance, the last scene closes in on the tip of Gojira's tale, from which many humanoid and grotesque looking monsters are spawning, bearing a strong visual resemblance with aliens or demonic mythological creatures.

The film's theory according to which the genderless Gojira is capable of asexual reproduction, supported for a long time by now, intertwines with the philosophical approach of the 
iconic monster with the souls of the soldiers and the victims of WWII, converging into a postmodern adaption of the leitmotif of reincarnation. More specifically, albeit a minor character referenced continuously during the story, the mysterious persona of disgraced biologist Goro Maki who left Japan after his wife's passing away, stricken by radiation sickness. Ostracized and expelled by the Japanese academic community, the elderly professor takes revenge either by unleashing the destructive power of Gojira or by fusing with the totemic beast. Hence, Gojira is Japanese by birth.

This potential human-monster fusion should be culturally interpreted in the context of the Shinto-inspired animistic belief system, where the borders between humans and nonhumans have a fluid and dynamic character. Therefore, the pervasive presence of animistic attitudes in the film is intimately connected with the legacy of Japanese folklore permeated with myths of hybrid morphing. It is by no means malefic or irrational but rather enraged the same way professor Goro Maki was, disappointed of his own country which has failed him and his wife, by helping the U.S. cover-up illegal disposal of radioactive waste into the ocean. Thus, its destructive power becomes justified, moral, and presents a cathartic effect.

As a criticism towards the consumerist society and global commodity culture it is diligently programmed to destruct, the construction of Shin Gojira privileges the resurgence of a subtly induced cultural nationalism. However, Godzilla as it is reimagined in the American film text, despite its engaging and overwhelming visual effects, lacks thematic and narrative depth, and it is orientated towards the psychological evolution and inner drama of the human protagonist, Dr. Mark Russell, interpreted by actor Kyle Chandler. Therefore, just like precedent American remakes, this one makes no difference in focusing on the inner drama or the selfhealing of a grieving father who has lost his son, ("vengeance" as emotion theme), while addressing the confrontation with Godzilla solely from a manicheistic perspective.

By purposely articulating the traditional values of family structure and the importance of gender roles, the narrative line aims to counterbalance its rich dystopian tone, seemingly announcing the impending end of the world. Hence, Godzilla engaging in battles with other monsters allegorically resembles the struggle of the human race confronted with an irrational evil and an implacable enemy of the human race, all these in a visually apocalyptic background 
of total physical destruction. However, what stands apart as relevant for the American installment is its added dimension as a "cli-fi" film, which corresponds to the contemporary and increasing interest of the public agenda towards climate awareness.

Albeit not overtly mentioned in the text yet arguably persuasive, the narrative line hides an allusive but repetitive warning concerning the necessity of protecting the climate and nature, which are forced to face the negative consequences of globalization and postmodernity: pollution, overpopulation, poverty, global warming or genetic engineering. As specified in the script (Shin Godzilla, 2016)

Nature always has a way of balancing itself. (01:20:47 - 01:20:50)

Man does not control the laws of nature. (01:38:59 - 01:39:01)

Or otherwise said:

But these are not monsters. They are animals rising to reclaim a world that was once theirs. (00:12:08 - 00:12:11)

Its original and rightful rulers, the Titans. They are part of the earth's natural defense system. A way to protect the planet, to maintain its balance. (00:49:14 - 00:49:23)

Thus, confronted with the incomprehensible realities of environmental changes metaphorized as reflections of the society itself, the American public is compelled to reconsider humans' place and role within all universe.

\section{The portrayal of shin gojira/godzilla and other characters}

The above-noticed difference leads to underlining the divergence in the portrayal of the iconic beast in two significant but interconnected alter egos: "the other" and "the enemy." On the one side, Shin Gojira becomes a part of a Shinto inspired and intrinsically dual universe predicating for good and the evil as complementary forces, thus acts similarly with its predecessors, seemingly an angry god, who closely follows an inner logic of destruction, and to some extent, self-destruction, culturally recognizable on a national level.

Moreover, through the lenses of the Japanese audience, in its quest to re-establish the equilibrium and to correct the sin of forgetting one's past, the monster can hardly be considered a genuine enemy; thus, it rises above the stereotypical yet cinematographically confiscated ideals of good and evil. 
Gojira. What does it mean? (...)

On Odo Island, where he's from, it means "God incarnate". (00:39:13 - 00:39:22)

Furthermore, except for Rando Yaguchi, a competent and rational junior minister devoted to public service and the only one who perceives the real threat, most human characters are politicians who lack humanity and dignity, preferring to prioritize their social status as in career and reputation over human lives. The antithesis between Yaguchi's devotement and allusive nationalism versus the rigidity of the old politicians who represent the peak of an exploitative socio-political system and remain stuck in meaningless and long-lasting debate marks the existing intergenerational gap in Japan, where the young generation faces both timeless but also modern anxieties without precedent. The sarcasm embedded in these scenes reflects wide-ranging post-contemporary concerns of the Japanese society struggling to protect societal norms, yet also forced to face the disturbing consequences of encouraging urbanization, industrialization, and its increasingly technologized status.

On the other side, the Hollywood production keeps character and plot innovation to a minimum. Here, Godzilla is integrated within a universe of good versus evil as perpetually conflictual forces, encompassing the threatening, destructive other and perpetuating the manicheistic interpretation of the world, which is historically and culturally rooted in the Judeo and Christian system of belief.

Without well-established narrative patterns or original subtexts, this Godzilla represents for most of the story a tangible foe, the reason why its weakened, and superfluid identity is reduced to one single dimension, the one of embodying malefic forces of chaos and illogical destruction, while perpetually threatening the cosmos and the world order. Regardless of the incontestable rich cinematic visuality, it lacks precisely the cultural, historical, and social relevance in which its Japanese counterparts abound.

The leitmotif of the rightful American hero who saves humanity from a pessimistic future projection accompanied by uncertainty and despair is well balanced with the objectification per se of the iconic beast. Most characters make melodramatic and sacrificial choices by putting their lives in danger to save the destiny of humanity and the future of planet Earth. As an example, doctor Serizawa and Mothra choose to sacrifice themselves to save Godzilla, and the 
bittersweet ending reveals the Russell family grieving and even more shattered by Emma's passing away. Hence, by adopting these stereotypical subthemes, the portrait of Hollywoodmade Godzilla registers a partial failure in its dramatic and cinematographic persuasiveness.

\section{The cultural encoding and reception differences}

Albeit both productions explore to some extent universal ideals, values, and dominant shared anxieties, each film has its cultural particularities which contribute to giving insight into various and complex socio-cultural realities of each society, as producer and consumer of the cinematic texts. However, it does not signify the ability to transcend all the cultural borders merely through translation.

The value of this subsection lies in acknowledging and interrogating the existing tension between the cultural specificity of Japan, respectively, the USA, as reflected in the selected films. Furthermore, understanding what culturally rooted attitudes shaped the narrative development, together with visual and aesthetic elements of each cinematic text, can reveal distinctive underlying perspectives that have shaped the process of reception within the globally dispersed context of the film industry.

What one could call the "Japaneseness" of the production is prone to face the reception danger of becoming, to a large extent, untranslatable to international audiences. From the Western perspective, for a viewer with very little to no understanding of Japanese mythology and tradition, encompassing the essence of monstrosity as Shin Gojira displays, it is highly likely a difficult task.

Thus, the iconography of Shin Gojira is reinforced as a signifying figure of a much larger and elaborate popular mythology whose functioning is enabled within Japan's cultural and, subsequently, national borders. Moreover, the iconization and narrative positioning of the beast is rearticulated as a personified expression of a variety of political, social, economic, and ideological discourses.

A fundamental culturally-rooted philosophically difference lies in the importance attributed to the concepts of shared human responsibility and questioning the expected conformity so societal ways and norms. "Shin Gojira" reveals the rigidity of contemporary Japanese society organized around immutable accepted standards, signifying the peace and harmony on 
a micro and macro level, which are, however, severely disrupted by the appearance of the mutated monster.

Along with these norms, seemingly insignificant gestures are interweaved in the narration, yet leaving the Japanese public with complex significations and inviting them to further interpretation. For instance, the leitmotif of taking off the shoes before committing suicide, just like professor Goro Maki did, is filled with suicidal angst, which is highly likely to be culturally confiscated and to become of an impenetrable opacity for the usual American spectator. Another Japanese culturally specific trait that has shaped the structuring and syntax of the film is the permeability of the border delimitating the physical and spiritual realms. More specifically, as an angered god and as a metaphor for the souls of the fallen soldiers during WWII and the victims of March 2011, Shin Gojira, reinforces, just like its predecessors, the necessity of extracting oneself from a ritualist and comforting oblivion towards Japan's past. Once again, the Imperial Palace of all the other buildings residing in Tokyo is spared of its apocalyptic force, being more likely voluntarily, yet predictably omitted.

The following fascinating particularity of Japanese traditional culture also reflected in the syntax of "Shin Gojira" is how it draws on the dichotomy "Giri" - "Ninjō" ("Duty" and “Emotions”, 義理 - 人情). Similar to many Japanese narratives, the movie reinforces that the Japanese perception of morality is founded on questioning the honourability, responsibility, and duty of one's behavior toward the group or the society to which he belongs. As a consequence, in the film's cultural narrative, figures such as Rando Yaguchi and Goro Maki display behavior which, through the lenses of Western socio-ethical standards, could be perceived as unacceptable. However, in this context, it is culturally reinforced as socially accepted. Yaguchi stands up to his supervisors by disobeying them but has in mind a much higher ideal: the one of protecting the future and reputation of Japan. Maki fulfills his familial responsibility to defend his wife's memory to the utmost, by sacrificing his life in an attempt to revenge her useless death, ("vengeance as duty" theme) although there are many interpretations regarding this theory.

On a similar note, the Japanese American character, Kayako Ann Peterson, the American envoy to Japan, could easily stand for the alienated Japanese returnee (“kikokushijō”, 帰 国子女) who has lost to a large extent her connection to the community. Albeit of secondary 
importance, through her role, the film tackles the concern of the transnationalist imagining of Japan and renegotiates the sensible issue of diasporic identity and homeland reconnection. Her overtly sexualized behavior privileging emotions (“ninjō”, 人情) above her social responsibilities, heavily influenced by the adoptive American counterculture, might make her disagreeable, yet her character manages to attract sympathy when drawing off her Japanese roots. As a whole, every personage, not only the ones aleatory mentioned above, displays both positive and negative potential, whereas no one can be considered inherently good or evil, thus supporting the above mentioned Shinto notion of dualism.

What bolsters the Japanese cultural distinctiveness of the film also lies not only in presenting overtly a vocabulary of national stereotypes but also in emphasizing the historical, architectural and geographical specificity within the narrative line, by referring to particular locations such as Ginza Chuo Ward or buildings like the National Diet Building in Nagatacho, Japan Meteorological Agency, and the Tokyo Station with its famous red-brick built Marunouchi frontage.

Along with the above mentioned local and consequently temporal contextualization as well, a semiotic interpretation of the Japanese language narrative subtext is prone to emphasize significant disparities in the reception process: words such as "earthquake" (地震) or "tsunami” (津波) have the potential of converting themselves into national allegories of emotions, thus should be interpreted within the historical and geographical borders of Japan.

Not lastly, the subtlety yet the high importance of Japanese honorifics (“Keigo”, 敬語) as used in the original script should not be omitted, considering that it dictates to a high degree the nature of social relations and its cross-linguistic translatability (Japanese - English) remains disputable:

I'm bad at Japanese honorifics.

Can we go informal? (00:42:02 - 00:42:06)

In terms of cultural encoding and reception differences, at the opposite pole, lies the American cultural specificity of "Godzilla: King of the Monsters" (2019).

What reflects the anxieties of contemporary America is the subtheme of alien invasion, portrayed by King Ghidorah's alien and hostile nature, who has arrived on Earth and attempts 
to perform a hostile takeover of the planet. Overall, the presence of the four kaiju could be easily interpreted as an allegory for America's fear of isolation, revealing an existential threat for humanity as a whole, the one having to face human's condition as weak and not in the center of Creation anymore.

Thus, by relating to the human-centered universe approach deeply embedded in Western philosophy, the film also exemplifies the potential danger of having the Earth colonized and, as a consequence, suggests how close we can get to imminent extermination of the human race. Thus, to interpret the logic of the American public's emotions towards Godzilla, it becomes necessary to refer, once again, to the context of "Self - Other" dichotomy and the cultural individualism which permeates the narration of the Hollywood production. This observation explains on a micro level the narrative interest towards the drama of an individual family grieving the death of their son and on a macro level, why the human characters and oppositional forces and antagonist existences. In contrast, the opposition between the "attacker" and "the attacked" is much stronger than in the Japanese film.

What also adds American cultural value is the spatiotemporal contextualization, such as bounding Godzilla and inherently, the other monsters, to American cities such as Boston or Washington DC, iconic and emblematic buildings as Washington Monument, the Capitol Building or the John Hancock Tower of Boston. Whereas in terms of reception, it becomes essential to mention the linguistic impact of popularising the Japanese monster within the cultural and geographical borders of USA: the suffix "-zilla" has been appropriated by American slang and employed to denote compelling, angry and ugly objects or beings, while emphasizing their appealing and monstrous character: Bridezilla, Momzilla, Shopzilla, etc. Therefore, its pejorative nuance alongside its unstoppable popularisation as a floating signifier points out the subconscious reaction of the American public towards a kaiju such as Godzilla: it remains undesirable and grotesque.

\section{Imaginary and aesthetics of destruction}

The dichotomy West-East is also reflected in the imaginary and aesthetics of destruction, overwritten through the repressed imagery of chaos, which has different meanings for each of the films discussed in the present analysis. 
Whereas for the Japanese cinematographic production, the imminence of world destruction and facing the ultimate destiny of humanity bears some resemblance to the lamenting tone of the typical eschatological narratives engaged in numerous Hollywood productions. Yet, it takes some distance from placing the apocalyptical and dystopian theme in the historical epicenter. Therefore, the Japanese film refrains from embracing the dark and dystopian tone of the American remake but instead accepts with dignity the potential apocalypse as the chance for a fresh beginning.

The capital and government are in shambles.

Destruction gives us a chance to rebuild it right. (01:50:34 - 01:50:46)

The aftermath imagery of ruins left behind by the destructive Shin Gojira becomes an instrument for communicating a variety of socio-cultural and historical anxieties, but it also serves to the intense memorialization of the past and the ancestors.

I won't see a third bomb dropped on the country of my grandmother, who lived through

it. (Kayoko Ann Patterson) (01:18:33 - 01:18:42)

More specifically, Shin Gojira personifies the 2011 tsunami, earthquake and Fukushima Daichi Nuclear Power Plant disaster all in one post-apocalyptic panorama abounding in meaningless death and destruction, generated solely by humans' egoistic and materialistic desires.

Wishful thinking and armchair theories by the old Imperial Army in the last war led to 3 million Japanese lives lost

Beware of unfounded optimism. (00:22:52 - 00:23:04)

The targets of its impressive destructive actions should be interpreted in Japan's critical context facing the consequences of post-war economic growth, more specifically as a criticism towards the substantial and persistent crisis of capitalism and consumerism. This potential cathartic lurking in the scenes of mass-destruction resonates more likely with the Japanese audience than with the American one. From this perspective, Shin Gojira's emergence reflects similarly with previous installments the symptomatology of a self-blaming nation looking to redeem itself, even by displaying masochistic tendencies.

Maybe releasing this destructive God as a sort of test...of mankind, this country, we Japanese. (01:32:13 - 01:32:23) 
Albeit the American remake of 2019 cannot connect whatsoever to a historicallygrounded atomic threat and its ravishing memories, it revolves in no small extent to a long chain of mostly imagined but also real anxieties concerning the national security and the prospect of facing a potentially invincible attack launched by a hostile outsider. Thus, unlike the Japanese film and as reflected in the narrative exposition and visual development, this media production does not reflect the nation's empirical reality but rather a subtle atmosphere of culturalized anxieties woven around the plot:

Our world is changing. The mass extinction we feared has already begun, and we are the cause. We are the infection. But like all living organisms, the earth unleashed a fever to fight this infection: its original and rightful rulers, the Titans. For thousands of years, these creatures have remained in hiding around the world. And unless all the Titans are found, our planet will perish, and so will we. They are the only guarantee that life will carry on. (D r. Emma Russell) (00:48:54 - 00:49:40)

Whereas America's cultural fear of imminent destruction has already entered the speculative horizons of most ordinary citizens, it becomes difficult not to interpret the monster's actions simultaneously with the mass-scale visual violence flourishing in the Hollywood industry. The American public exhibits both a morbid fascination and extreme fear towards imagining the process of self-destruction, and the cathartic point is reached when the hero brings the much-expected saving, just a few moments before the ecstatic and complete ruination.

\section{Conclusions}

The present research does not pretend to offer a comprehensive view of Gojira/Godzilla, hence the decision to focus only on two cinematographic productions during the analysis. However, through its flexible analytical approach, it investigates differences in cultural representation in two national contexts. Hence, through a comparative analysis of the selected films, the author has examined the contrastive nature of Gojira/Godzilla in the Japanese, respectively, American context of production, exhibition, and reception. In this respect, a particular issue worth considering that arises after comparing these media texts is that the existing frictions and discrepancies converge into pointing out the difficulty of transferring the elusive Japanese na- 
ture of the iconic monster into the realms of an increasingly globalized cinematographic industry.

Whereas similarities to some extent are inevitable, the noticed differences and the icon's distinctiveness in the dynamics of global film industry play an instrumental role in underlying not only the cultural specificity of each movie rooted in a much broader economic, geopolitical and historical context but also in pointing out its seemingly superficial transnational appeal. Furthermore, Shin Gojira remains, just like its predecessors, inherently national, thus should be identified with or at least attributed to Japan, even though the iconic beast does not remain self/contained within the Japanese film industry given the recurrent Hollywood adoptions of its mode of representation. Hence, the strategy of reconfiguring Gojira as its American twin has enabled the American audience to appropriate a pearl of wisdom otherwise most likely unachievable, surpassing the continent's geopolitical and historical borders. At the same time, the iconic narration still blends in a particular manner the personal and social dynamics of the characters.

As a conclusion, instead of thinking of Gojira/Godzilla as a popular icon with two nationalities which are symbiotically connected to a collective identity and share a culturally diverse heritage, the author prefers to associate it with the image of twin icons. Metaphorically speaking, both were born, raised, and now a days living in two different countries, each one displaying and maintaining its particular identity which is simultaneously distinctive but also culturally ambiguous. Its ambiguous character is by no means a consequence of its mode of production, representation, or other industrial practices but is due more likely to the public's intellectual approach and flexible perception of the mutated monster. Nevertheless, what only seems to undermine its culturally emphasized distinctiveness, either Japanese or American, is not merely the cultural performance of the iconic beast but the global public's dynamic perception, expectations, and, as a whole, the contrastive modes of receptions. 


\section{References}

Głownia, D. (2013). Socio-political aspects of kaijū eiga genre: a case study of the original godzilla. Silva Iaponicarum XXXVII. https://www.academia.edu/13808136/Socio-Political_Aspects_of_Kaij\%C5\%AB_Eiga_Genre_A_Case_Study_of_the_Original_Godzilla.

Godzilla: King of the monsters. (2019). English language script. https://www.opensubtitles.org/en/search/sublanguageid-all/idmovie-594890. Accessed 29 May 2019

Hashimoto, A. (2016). Tradition and modernity in Godzilla: The implications of changing perceptions of monsters. Journal of Kyoto Seika University, 48, 186 -187.

Honda, I. (2010). Godzilla and the movies of my life. Wanibooks [PLUS] New Book 43, (Japanese ed.). Alligator Plus.

JICC Press. (1992). Introduction to monster studies! (Additional Volume No.2 Takarajima Series, Japanese ed.) JICC Publishing Department. Takarajima Publishing House.

.Kato, N. (2010). Goodbye to every Godzilla, drifting far away after the war (Japanese ed.). Iwanami Shoten Publishing House.

Kawamoto, S. (1983). Why is Godzilla so dark? (Japanese ed.). Shingeki Hakusuisha Publishing House.

[Koukoku project: why is the death of Godzilla sad? Godzilla and the myths of Japan and Shinto]. (2013). http://blog.livedoor.jp/kokoku2700/archives/46620195.html

Milenkova, V. Peicheva, D., Marinov, M. (2018). Towards defining media socialization as a basis for digital society. International Journal of Cognitive Research in Science, Engineering and Education (IJCRSEE), 6(2), 21-31. doi:10.5937/ijcrsee1802021M

Mikihiko, O. (2001). Meiji and noble: maresuke nogi (Japanese ed.). Tendensha Publishing House.

Ryfle, St. (2005). Godzilla’s footprint. Virginia Quarterly Review, Winter, 81(1), 44-63.

Shibuya, Sh., et al. (2010). Shinto Shrines: An Introductory course through illustrations you might seem to know yet are unexpected (Japanese ed.). Yosensha Publishing House.

Shin Godzilla (2016). English language script. https://www.opensubtitles.org/en/search/sublanguageid-all/idmovie-469798.

Tabata, M. (2005). Why does Godzilla destroy cities? (Japanese ed.). Studies in Urban Culture (5), 16-29. 
Takei, Y. (2016, 23.08). Why do Japanese keep making Godzilla movies? (Japanese ed.). Diamond Online newspaper. https://diamond.jp/articles/-/99586

Tanaka, T. (1984). Introduction to Godzilla (Introductory Encyclopedia Series 142. (Japanese ed.). Shogakukan Publishing House.

Tanaka, F. (1991). The novel: Godzilla vs. King Ghidorah (Sonora Manovels). (Japanese ed.). Asahi Sonorama Publishing House.

Toho. (1984). Godzilla theater pamphlet (Japanese ed.).Toho Publishing House.

Tsutsui, M. W. (2017). Godzilla on my mind: fifty years of the king of monsters. St. Martin's Publishing Group.

Tsutsui, M. W. (2005). Godzilla and half a century in the United States. (Japanese Ed.). Chuokoron-Shinsha Publishing House.

Turner, T. (1967). Betwixt-and-between: The liminal period in rites de passage. In the forest of symbols: Aspects of the ndembu ritual. Cornell University Press. https://brunel.rl.talis.com/items/FC0877AE-B134-D5B3-FD41-E1C2D991F889.html

World Photo Press. (2009). Godzilla revitalized. (Japanese ed.). Figure King, 133. 